\title{
The reproduction of privilege: Young women, the family and private education.
}

\section{Claire Maxwell*}

Department of Humanities and Social Sciences, Institute of Education, University of London, London, UK.

\section{Peter Aggleton}

Centre for Social Research on Health, Faculty of Arts and Social Sciences, The University of New South Wales, Sydney, Australia.

Claire Maxwell is a senior lecturer in the sociology of education in the Department of Humanities and Social Sciences at the Institute of Education, University of London. Her research interests focus on the concept of agency, the private education schooling sector, and elite families' processes of cultivation and reproduction. Together with Peter Aggleton, she has recently led an ESRC supported study entitled Top girls: middle class privilege and agentic practice.

Peter Aggleton is Professor of Education and Health in the Centre for Social Research on Health at The University of New South Wales, Australia. Together with Sally Power (Cardiff University) and Michael Reiss (Institute of Education, University of London), he co-edits the prestigious Foundations and Futures of Education series of books published by Routledge.

This work was supported by the UK Economic and Social Research Council under Grant [RES-062-23-2667].

* Corresponding Author c.maxwell@ioe.ac.uk 
Maxwell, C. \& Aggleton, P. (2014) The reproduction of privilege: Young women, the family and private education. International Studies in Sociology of Education 24(2): 189-209.

\section{The reproduction of privilege: Young women, the family and private education.}

The paper examines processes of cultural production and reproduction among members of the elite and upper middle classes. Drawing on findings from a study of private education in England, it explores the utility of a conceptual framework to examine how practices in and across different sites may be reproductive of various forms of 'privilege'. Three domains in particular - family, the school, and individual young women's projects of the self - together shape key meanings and orientations informing young women's lives. These meanings and orientations in turn connect to 'privileging practices', both within each domain and beyond. The paper analyses data from three young women in one of the schools studied to illustrate how the framework may be used to examine privately educated young women's different orientations to the present and the future. Findings point to some of the processes through which class and gender privilege may be variably reproduced.

Keywords: family; private education, class, social and cultural reproduction, privilege. 
Maxwell, C. \& Aggleton, P. (2014) The reproduction of privilege: Young women, the family and private education. International Studies in Sociology of Education 24(2): 189-209.

\section{Introduction}

Recent sociology of education has sought to examine the influence of schooling and family practices on processes of cultural and social reproduction (Allan, 2009; Archer, 2011; Crozier, Reay, \& James, 2011; Hollingworth \& Williams, 2009; Pini, McDonald, \& Mayes, 2012; Power, Curtis, Whitty, \& Edwards, 2010; Reay, 2007; Vincent \& Ball, 2007; Vincent, Rollock, Ball, \& Gillborn, 2012). Studies of middleclass identities, as well as the construction and practice of social class distinction and 'Othering', have drawn on the valuable conceptual frameworks offered by Bourdieu: in particular his work on social and cultural capitals and on habitus (Ball, 1997; Ball, Vincent, Kemp, \& Pietikainen, 2004; Clark, 2009; Horne, Lingard, Weiner, \& Forbes, 2011; Lawler, 2005; Méndez, 2008; Meo, 2011; Reay, Crozier, \& James, 2011; Thomson, 2000).

In this paper, we seek to engage with the above literature influenced by Bourdieusian understandings of social and cultural reproduction, but also aim to extend it through a specific focus on the concept of privilege within the context of private education in England. We suggest the value of a focus on 'privilege' not only because of the socio-cultural location of the young women in our study and the schools they attended, but also because the concept captures well the material, cultural and ideological resources accessible to this particular group, and their role in processes of social differentiation and hierachisation. We define the term in greater depth further below.

Our specific focus is on how current and future, what we have called 'projects of the self' among young privately educated women are shaped by the family and school (and the resources they make available). Such projects of the self articulate meanings 
Maxwell, C. \& Aggleton, P. (2014) The reproduction of privilege: Young women, the family and private education. International Studies in Sociology of Education 24(2): 189-209.

and orientations which, in turn, drive the social practices of young women both in and out of school. Our analysis examines the potential of these practices to reproduce privilege for families who, through the choice to educate their daughters privately, expect this to increase the potential for future educational, employment and social success (Allan \& Charles, 2014; Forbes \& Lingard, 2013; Koh \& Kenway, 2012). Critical to our analysis is a focus on how processes of cultural and social reproduction are shaped by the family, the school and the young person themselves, as well as on the ways in which privilege is and is not always reproduced.

\section{Understanding the role of family and school in reproductive practices}

A substantial literature focusing on the influence of social class in relation to educational outcomes emphasises the key role played by the family (Archer, 2010; Ball \& Vincent, 2007; Bernstein, 1977; Brantlinger, 2003; Connell, Ashenden, Kessler, \& Dowsett, 1982; Irwin \& Elley, 2011, 2013; Lareau, 2002; Reay et al., 2011; Stefansen \& Aarseth, 2011). Recent research has stressed the value of 'close focus' research examining the interface between the family and the school. Vincent et al. (2012), for example, examined Black middle class parents in England and their educational practices in relation to schooling. Through a focus on dispositions towards education and the possession and activation of different 'capitals', these authors identify four main groups of families who were all actively involved in their children's schooling, but who had subtly different orientations in relation to 'academic achievement'. Parents who were 'determined to get the best', 'watchful', 'fighters' or 'hoping for the best', embodied 'differential family habitus, and differential possession and activation of capitals' (Vincent et al., 2012, p. 337) which arguably impact on the ways their children 'succeed' in their schooling. Elsewhere, Davey (2012a) has drawn on the notion of 
Maxwell, C. \& Aggleton, P. (2014) The reproduction of privilege: Young women, the family and private education. International Studies in Sociology of Education 24(2): 189-209.

habitus and capitals to distinguish between three different types of middle class families attending one private school in England, examining how family university education histories directly shaped students' own university decision-making processes. These and related studies highlight the importance of examining variations within the middle classes (i.e. between fractions), as these are 'what served to distinguish [Davey's middle class students and] ... helped to deconstruct the sometimes vague notions of privilege' (Davey, 2012a, para 2.5).

Other writers have focused on the role of the schooling context in shaping parental decisions and young people's future orientations (Allan, 2010; Forbes \& Lingard, 2013; Horne et al., 2011; Proweller, 1998). Forbes and Weiner (2008), for instance, examine how different forms of capitals are made visible via the websites of four Scottish private schools and how these shape the orientations of each school (and ensuing parental choices) as well as the different forms of privilege institutions advertise themselves as seeking to reproduce. Davey (2012b) demonstrates how the private school in her research becomes a producer of cultural capital, specifically in relation to university choice, and stresses the importance of parental desire in wishing to consume the 'symbolic display ... [of] academic credentials and university destinations' (p. 521). Forbes and Lingard (2013), in their analysis of one elite girls private school, go further to show how individual headteachers are critical in shaping the habitus of the school and the capitals that are valued, leading to the reproduction of 'physicalcorporeal, social and intellectual surety, accomplishment and agency for students' (p. $50)$.

Finally, several studies of social class and education examine how dispositions and orientations shape outcomes - both within a specific educational context or more generally (Allard, 2005; O'Flynn \& Petersen, 2007; Reay, Crozier, \& Clayton, 2009; 
Maxwell, C. \& Aggleton, P. (2014) The reproduction of privilege: Young women, the family and private education. International Studies in Sociology of Education 24(2): 189-209.

Renold \& Allan, 2006; Thomson, Henderson, \& Holland, 2003). Here, Bourdieu's concepts of capital are drawn upon to analyse how individual resources interact with the broader context to shape individual trajectories. Clark's (2009) study of six young women transitioning from primary to secondary school examines how family "understandings of "a good education" affect both academic and extracurricular/sporting choices' (p. 601). Her work reveals how parental background and histories strongly shape young women's decision-making processes in relation to desired educational outcomes and their orientations to extra-curricular activities.

A growing set of studies examine processes of cultural and social reproduction among young people attending elite schools (Allan, 2009; Allan \& Charles, 2014; Charles, 2010; Forbes \& Lingard, 2013; Gaztambide-Fernández, 2009a; GaztambideFernández, Cairns, \& Desai, 2013; Horne et al., 2011; Howard, 2008, 2013; Kenway, Fahey, \& Koh, 2013; Khan, 2011; Koh \& Kenway, 2012). However, much of this work remains under-developed in several respects. First, many studies to date have focused on one school only, which makes it difficult to discern how different upper middle class fractions use the private education system as a whole to attain their goals, and how different groups use different schools in an attempt to secure the best future for their children. This is in contrast to research with working and middle class parents and families. Power et al.'s (2010) important study of the use of the Assisted Places Scheme in England, for example, paid close attention to the choices and practices of different class fractions and their experiences in different schools that were part of the Scheme.

Second, relatively few studies examine how the three inter-linked domains of the family, the school and the self intersect to produce the orientations and social practices that contribute to cultural and social reproduction (but see Proweller, 1998 and Hollingworth, 2013 as exceptions). Gaztambide-Fernández (2009) and Khan 
Maxwell, C. \& Aggleton, P. (2014) The reproduction of privilege: Young women, the family and private education. International Studies in Sociology of Education 24(2): 189-209.

(2011) touch upon such concerns in their ethnographies of two elite boarding schools, but focus largely on differences between study participants from elite families or those from less wealthy, minority ethnic families.

We therefore suggest that a renewed emphasis on how different families, young people and private schools together shape practices and processes of reproduction, is required. This we seek to do in the present study, which focuses on levers and barriers to cultural and social reproduction among elite, and also upper middle class girls attending fee-paying schools in England.

\section{The study}

The findings described here derive from a longitudinal, qualitative study of young women being privately educated in four secondary schools in one area of southern England. Against the background of a concern to examine cultural and social reproduction, our interest lay in understanding how privileged social class locations make available possibilities for practices that are agentic in relation to interactions with families, peers and schooling. Put simply, our work sought to explore young women's understandings of their worlds and extend the ways in which the concept of 'agency' might be used to make sense of their capacity to act, while also attending to the effects of such action for the reproduction of class and gender relations.

The geographical area chosen for the study was a relatively large political and administrative county containing several large towns as well as many rural areas. There are a large number of private secondary schools in the county - and the four institutions recruited to participate in the study were illustrative of the different kinds of schools within this locality. Two were boarding schools and two were day schools; two were single-sex institutions and two were co-educational; one of the single-sex schools was 
Maxwell, C. \& Aggleton, P. (2014) The reproduction of privilege: Young women, the family and private education. International Studies in Sociology of Education 24(2): 189-209.

highly academically selective; one of the co-educational schools was considered a real 'traditional public school' (with a long history and many well-known alumni).

Access to the schools proved relatively straightforward. The first author had a long-standing relationship with the co-educational boarding school - having conducted a doctoral study there, as well as a subsequent research with her co-author on young women's experiences of sexual and intimate relationships. One of the members of the senior leadership team at this first school, had since moved to run the Sixth Form (Years 12-13) at another private school nearby, so access to a second research site was facilitated by this prior relationship. The other two schools in the sample were initially contacted via email, after which the first author was invited to meet with the Head or Deputy Headteacher, and subsequently secured access into these schools as well.

The main focus of the work involved interviews with a minimum of twenty young women across Years 10-13 (aged 14-18 years) in each of the four participating schools, with two-thirds of the informants being re-interviewed 12-18 months later. An email and information sheets were sent out to all young women across these Year Groups, inviting them to participate. All those who responded were involved in the study. During the interviews, we explored how young women described themselves, why they (and their parents) chose the particular school they attended; their family situations; examples of positive and negative experiences, especially where they felt more or less in control; parts of their lives they felt most confident about, what they were less sure about, and so forth. All 147 interviews (91 first interviews and second interviews with 56 of these participants) were conducted by the first author and fully transcribed. Additional interviews were undertaken with members of the senior staff teams in each school (11 in all across the four schools) with a focus on the ethos and future direction of the school. Finally, the first author spent time observing lessons and 
Maxwell, C. \& Aggleton, P. (2014) The reproduction of privilege: Young women, the family and private education. International Studies in Sociology of Education 24(2): 189-209.

school life more broadly (spending between 2-5 days at each research site). Data collection took place between January 2011 and December 2013.

Informed by our argument that 'the home', 'the school' and 'the self' interact to shape orientations and practices - we organised the data to inform our analysis in the following ways. First, 'the home' was made visible through an analysis of markers of social class location (parental occupation, where parents lived etc.) and narratives relating to how particular schools had been chosen. Second, 'the school' context was characterised by interview data from the school staff who described the uniqueness and culture of their school as well as the kinds of families whose children attended it. Comments made by young women about why they had come to that particular school were also engaged with here. Finally, 'the self' was narrated through the sections of the interviews in which young women described themselves and others, the experiences of family and friends, and their own future aspirations. This process of analysis resulted in an analytic framework whereby the home, school, and the self were viewed as influences shaping the dominant meanings and orientations each young woman adhered to, and the social practices to which these gave rise.

The study was reviewed and approved on ethical grounds by the (Faculty Ethics Review Committee) at the (Institute of Education, University of London). Data were collected with informed consent, and respondents, schools and their locations have been carefully anonymised. Study participants have been provided with pseudonyms as have the schools in which fieldwork took place. In addition, given the contested nature of private education in England, and the documented role it plays in the reproduction of class inequalities (Walford, 2012), in our analysis we have been concerned to explore both the culturally and social reproductive consequences of this form of education, as well as its more unintended effects, both for individual young women and for their 
Maxwell, C. \& Aggleton, P. (2014) The reproduction of privilege: Young women, the family and private education. International Studies in Sociology of Education 24(2): 189-209.

families. Our interest has lain in understanding how young women make sense of the benefits and opportunities afforded to them, but also the challenges experienced in attending some of the best resourced, high status schools in the country, together with the ways in which gendered and privileged subject positions may be being reconfigured within these spaces.

\section{Privilege, sureties and orientations to practice}

The term 'privilege' can be used to describe the set of self-understandings, dispositions and worldviews observed among young people and families, who largely see power as natural or unquestioned (Gaztambide-Fernández et al., 2013; Howard, 2008, 2013, but see also the literature on white privilege - McIntosh, 1990). Privilege is connected both to a person (as a set of attributes or as an identity) and to being embedded within a particular space - in this case a private/elite school - which 'shapes and interacts with subjects who cross or inhabit this terrain' (Maxwell \& Aggleton, 2013b, p. 4). Privilege may also manifest itself in expressions of 'surety' (Maxwell \& Aggleton, 2013a) such as having a unique combination of qualities and abilities; possessing a strong sense of affinity with and connectedness to other families and to the school attended; and/or having confidence about future educational and employment success. It is therefore bestowed through self-understandings originating within the self, the family and the school, strongly supportive of a hierarchised sense of personal and social 'difference' from Others.

Below, through the use of three case studies drawn from one of the schools participating in this study, we explore in more detail young women's engagement with these composite influences to produce particular kinds of surety and privilege, and the potential consequences of this for processes of cultural and social reproduction. Before 
Maxwell, C. \& Aggleton, P. (2014) The reproduction of privilege: Young women, the family and private education. International Studies in Sociology of Education 24(2): 189-209.

doing so, however, we offer a more detailed discussion of how we see the domains of family and school influencing young women's own perspectives and therefore their orientations to current and future practices, informed by our data analyses of the young women across our sample who were attending different kinds of private schools.

Figure 1. The shaping of orientations

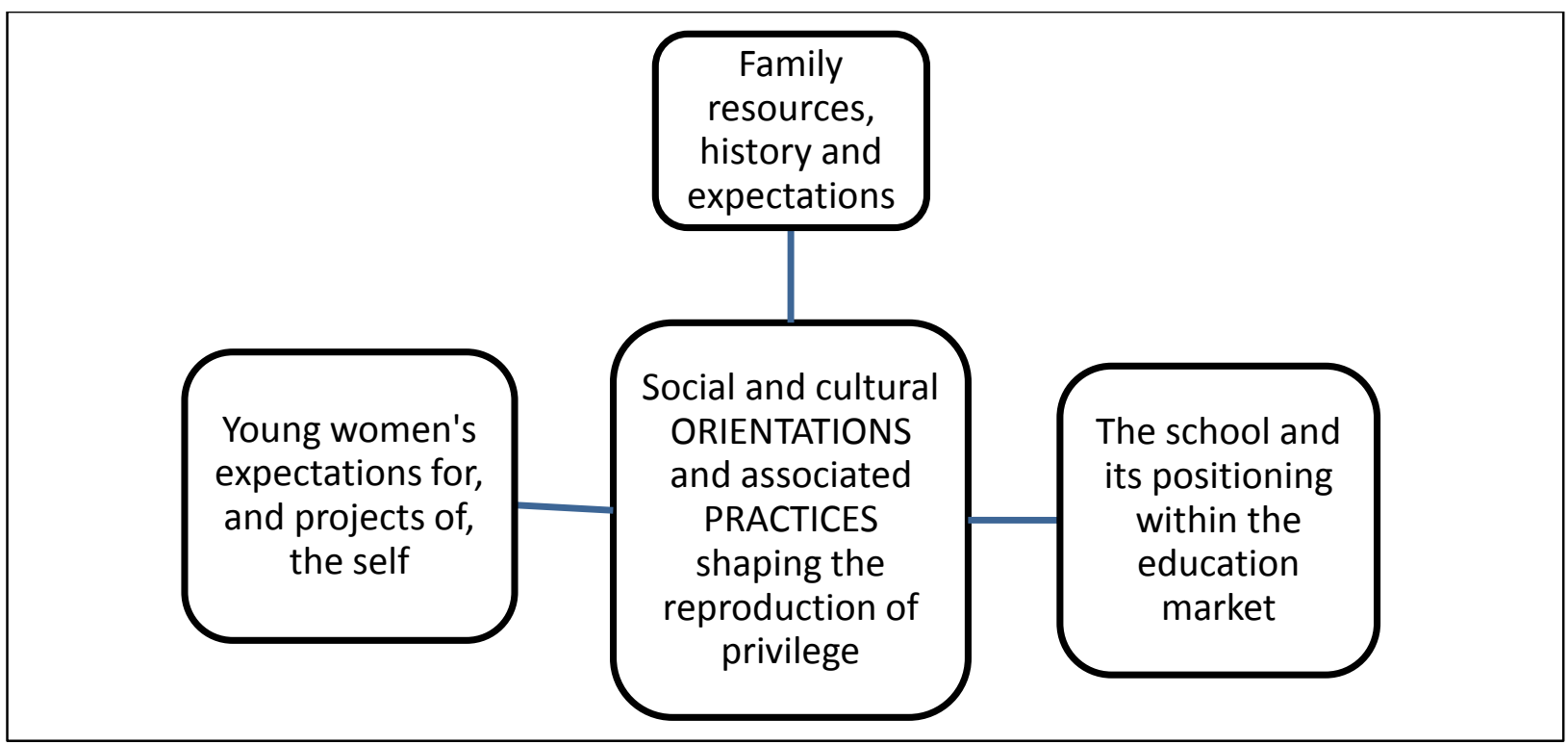

For some of the families in the present study, the decision to privately educate their daughters and the choice about which school to select, had been driven by a clear desire for concerted cultivation, stressing academic and social achievement above all else (Lareau, 2002; Vincent \& Ball, 2007). For others, however, a more concerned or nurturant form of cultivation had informed the choice of school for their daughter. For these parents, the right school was the one in which their daughter, first and foremost, felt safe and happy (Irwin \& Elley, 2011; Stefansen \& Aarseth, 2011).

Driven in part by these different parental outlooks were the orientations articulated by the young women in relation to how hard and consistently they felt they should work towards academic attainment, the extent to which they should become involved in certain extra-curricular activities, and the degree to which they should excel 
Maxwell, C. \& Aggleton, P. (2014) The reproduction of privilege: Young women, the family and private education. International Studies in Sociology of Education 24(2): 189-209.

in these endeavours as well. Many young women explained that so long as their parents felt they were striving to do well, then they would be satisfied with their achievements. Other young women, however, suggested that their attitudes to current and future educational aspirations had been strongly shaped by the successes or failures of older siblings (siblings' exam results, the anxiety sibling failure had generated for their parents, the type of university a brother or sister attended, etc). Thus, the family strongly shaped young women's orientations through the kinds of expectations imposed - either directly or in more subtly ways. Crucial as well, was the perceived engagement of parents in their education and broader lives and the affective nature of relationships between parents and within families. All these factors appeared to affect young women's projects of the self and desires for their futures.

The four schools in our study provided different cultures and expectations for their students, which in turn could be seen as shaping the orientations and expectations for the self-narrated by our participants. While all schools, superficially at least, presented themselves as seeking to develop confident, articulate and 'accomplished' young women - this goal was not pursued in the same way. Instead, schools' own histories, the ways they sought to position themselves within the broader (private) education market place, and the kinds of families they had traditionally and were currently seeking to attract, shaped their demands in relation to academic attainment and the ways in which they promoted the cultivation of accomplishment. 
Maxwell, C. \& Aggleton, P. (2014) The reproduction of privilege: Young women, the family and private education. International Studies in Sociology of Education 24(2): 189-209.

Table 1. The four schools in the study:

\begin{tabular}{|l|l|}
\hline \multicolumn{1}{|c|}{ School } & \multicolumn{1}{c|}{ Description } \\
\hline St. Thomas' & $\begin{array}{l}\text { Co-educational boarding school, seen as a } \\
\text { 'traditional public school' with vast grounds. } \\
\text { Relatively well-known nationally. Students come } \\
\text { from abroad, London and the surrounding areas. }\end{array}$ \\
\hline Brownstone & $\begin{array}{l}\text { Co-educational day school in a rural area with } \\
\text { many children being bussed in, some travelling } \\
\text { over an hour each way. The school occupies a } \\
\text { large space, with many sports facilities. }\end{array}$ \\
\hline Osler & $\begin{array}{l}\text { Single-sex (highly selective) day school, whose } \\
\text { catchment area is a large rural area. }\end{array}$ \\
\hline Rushby & $\begin{array}{l}\text { One of a declining number of single-sex girls' } \\
\text { boarding schools, which is set in very rural, large } \\
\text { grounds. }\end{array}$ \\
\hline
\end{tabular}

In the most academically selective school (Osler), for example, academic attainment was considered more important than well-rounded accomplishment. In Rushby School, by contrast, perhaps in part because it was a boarding school - extracurricular pursuits featured more prominently, with young women developing their accomplishment across a number of different domains (art, music, drama, debating and/or sport). At the second boarding school in our study, St. Thomas', while all students were required to take part in the extra-curricular activities (at least until the Sixth Form), few seemed to be pursuing these with the intensity or to the same level as observed at Rushby.

Despite differences between expectations of accomplishment and attainment driven by families and schools, all the young women in the study were focused on and continually engaging in projects of the self, linked both to the present and to the future. Their schools required them to articulate some form of future trajectory, as this was 
Maxwell, C. \& Aggleton, P. (2014) The reproduction of privilege: Young women, the family and private education. International Studies in Sociology of Education 24(2): 189-209.

central in trying to decide curriculum choices in the Sixth Form, and all schools espoused the importance of a university education. But projects of the self were also apparent in the way young women articulated understandings of themselves - in the kinds of personalities they had, the kind of friend/sibling/daughter they sought to be, the kinds of skills they wanted to develop or improve upon (for instance, being able to manage a university interview, being confident to go up to someone they did not know and make conversation, focusing more and getting their work done on time). Understandably, projects of the self were shaped to a large extent by dispositions and outlooks articulated within the home and the school, but also more subtly through the affective responses individual young women had to these norms and expectations, as well as the often unanticipated experiences of everyday life.

Turning now to young women's accounts of everyday moments and their future desires and plans, it is possible to identify some of the key meanings (orientations) driving the social practices of those who participated in our study. Using the framework identified earlier (Figure 1), in the following sections we seek to highlight the origins of these as well as the way in which they contributed towards the reproduction of privilege for three rather different young women in the same year, at one of the study schools Rushby School.

Rusby School is a single-sex boarding school, which draws its students from local families, as well as those in other parts of England. Its competitor schools are usually other well-known girls-only boarding schools in England (of which there are a decreasing number). Traditionally, Rushby has educated the daughters of the landed gentry, families with aristocratic 'titles' and the 'upper class' (Deputy Head, Rushby School). Despite a recent economic down-turn, the school has buoyant student numbers with many alumni sending their own daughters to be educated there and recommending 
Maxwell, C. \& Aggleton, P. (2014) The reproduction of privilege: Young women, the family and private education. International Studies in Sociology of Education 24(2): 189-209.

that other female family members do the same. In applying our framework to illustrate how the resources, histories and orientations made available in three different domains (the family, school and young women themselves) shape young women's orientations towards the future within the school and beyond, we will focus on three young women in the same year with quite similar backgrounds. We do this in order to illustrate how such a conceptualisation may facilitate an analysis of the ways in which relatively small differences at one or more of the three key levels of analysis (the family, the school and projects of the self) can affect orientations and consequent practices.

Sarah - surety of background, family and distinction

Sarah was 17 years old and in Year 12 when she was first interviewed. Both her parents had been privately educated - her father and all his male family members before him had been educated at Eton College, arguably the most elite all-boys boarding school in England. Her boyfriend also attended Eton.

She described her parents as happily married and as having a close relationship with her three sisters. Her father is a member of the House of Lords (the second chamber of the English Parliament), a position secured through a family-held peerage. He is also a very senior executive in a multi-national corporation. The family had a home in 'the country' as well as a flat in London. Her mother divided her time between their two homes - spending time with Sarah's father in London during the working week as well as pursuing yoga, participating in her book club and so forth, at their rural home.

When asked to identify a recent positive experience, Sarah talked about the birthday party held for one of her eldest sisters, explaining it was just 'really nice ... we 
Maxwell, C. \& Aggleton, P. (2014) The reproduction of privilege: Young women, the family and private education. International Studies in Sociology of Education 24(2): 189-209.

were all together'. When reflecting on any differences and similarities between herself and her siblings, Sarah concluded, 'my parents have brought us up to have manners and things ... but they haven't tried to make us anyone that we're not, you know'.

All four daughters within the family had been educated at Rushby. Sarah, as the second youngest sister, had felt very comfortable at the school, in part because her older sisters' year group had been 'friendly' and welcoming. Sarah described the school as, 'small ... everyone's laid back, everyone knows each other, it's all quite relaxed'.

When asked to describe herself, Sarah said, 'I'm quite academic ... I really enjoy drama ... yeah that's my thing.' Not only was Sarah intending to apply to study at one of the top universities in England - Cambridge - she had also been accepted to join the National Youth Theatre programme. When auditioning for a place on this programme, she had chosen, despite being 'probably one of the poshest ones there', to perform a monologue by a northern English playwright whose work was rather 'gritty'. As Sarah described it, 'Yeah I think it was just quite ... not what they [the programme directors] were expecting'.

In Sarah's case, as represented graphically in Figure 2 below, the economic and emotional security provided by her family background strongly influenced her orientation towards education and her future - as one that should be secure and successful, and in which efforts would be recognised and rewarded. Such affective reinforcements of Sarah's project of the self were re-inforced by attending a school which was not only a 'home-from-home' (most of its students had similar family backgrounds and it had provided a successful educational experience for all her sisters), but also was a space that recognised and celebrated both her academic achievements as well as her passion for drama. Together, these experiences were reflected in Sarah's 
Maxwell, C. \& Aggleton, P. (2014) The reproduction of privilege: Young women, the family and private education. International Studies in Sociology of Education 24(2): 189-209.

image of herself as able and accomplished, appropriately ambitious ('quietly' so) and on course for Cambridge, where she would be able to pursue her acting interests via involvement with the world-renown Footlights company, as well as securing future employability in terms of a good degree.

Figure 2. The shaping of orientations - Sarah

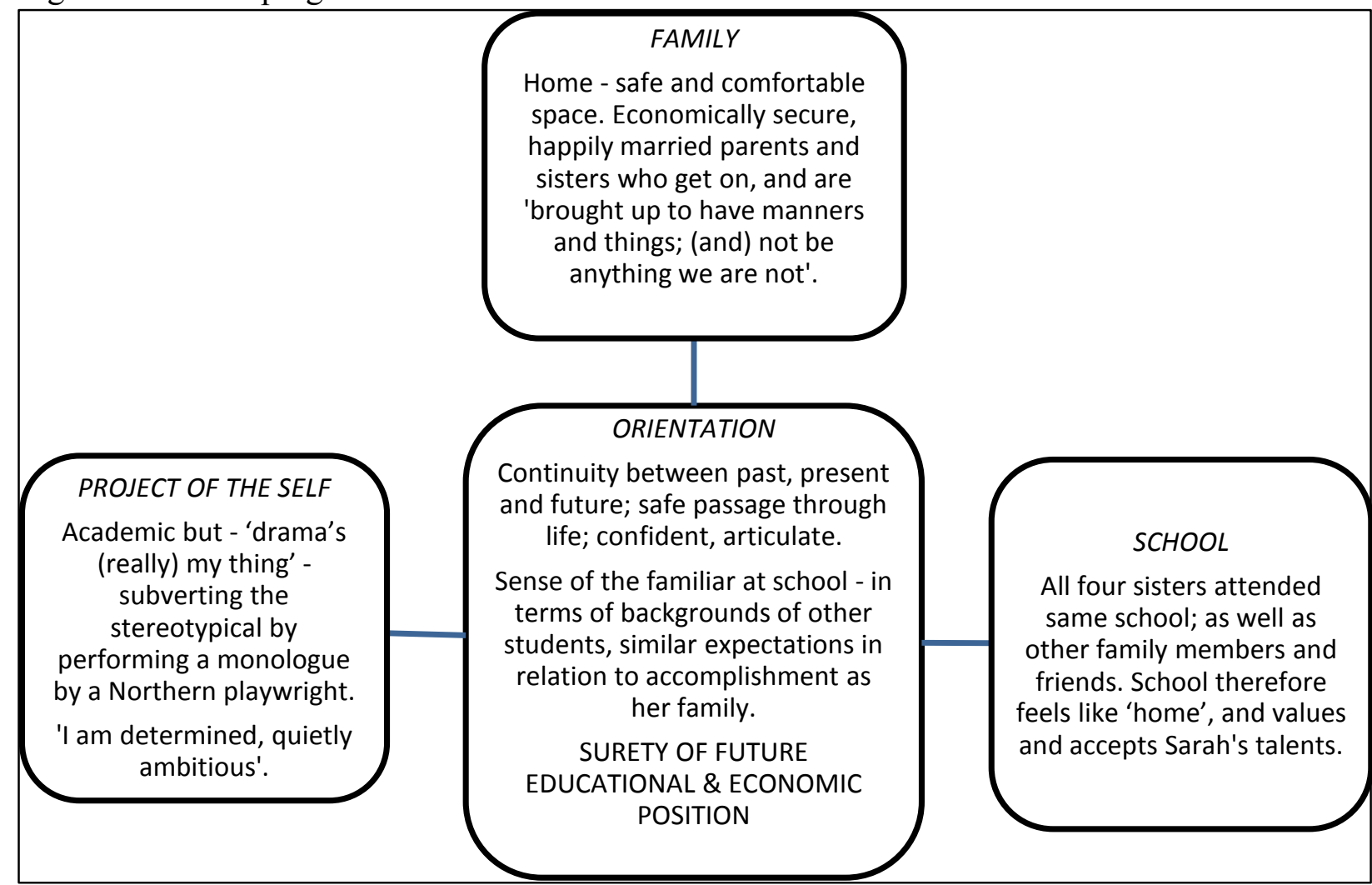

All of these experiences and resources informed by the pre-reflexive registers of meaning made available through family and school, and the creation of contemporary registers of meaning through the practices which Sarah herself engaged in (see also Nielsen, 2013; Maxwell \& Aggleton, in press) shaped her articulate and reflective positioning of herself during the interview. That her boyfriend was at Eton College also revealed strong continuity between Sarah's past (the tradition of all male members of her family attending the same school), the present (a link to this bastion of traditional, 
Maxwell, C. \& Aggleton, P. (2014) The reproduction of privilege: Young women, the family and private education. International Studies in Sociology of Education 24(2): 189-209.

upper class symbolism within England) and the future (the potential for partnering with someone from a very similar background and set of educational experiences).

Understanding Sarah's cultural and social orientation as informed by family, school and her own project of the self, offers a nuanced way of making sense of how past and present practices are likely to contribute to future success.

The continuity between Sarah's past, present and anticipated future in terms of her family experiences (feeling secure, potentially marrying someone from a very similar background), her connections to Rushby (happy memories of a fulfilling education, strong social networks developed through the school that will be maintained, perhaps sending her own daughters to be educated there) and her likely successful project of the self (either becoming an actor or securing employment due to a good university degree and via family and broader social networks) together contribute to the reproduction of privilege - particularly economic position, the socio-cultural network she is part of, and her approach to creating opportunities for herself through accomplishment. Sarah's orientation seemed uncritically to drive her practices (nothing in her experiences suggests to her things should be otherwise, or motivates the challenging of current power relations), which had the effect of reproducing particular family ideals (the male-breadwinner and the importance of family togetherness over individual achievement), the belief that meritocratic principles are pre-eminent (through hard work - success will be attainable in Sarah's academic and acting pursuits), and her faith that 'being oneself' (through embodying a particular set of manners) is an appropriate and a necessary way to behave. Together, these orientations set Sarah apart, above and beyond many of her peers, and ready to enjoy future success as part of the traditional British elite. 
Maxwell, C. \& Aggleton, P. (2014) The reproduction of privilege: Young women, the family and private education. International Studies in Sociology of Education 24(2): 189-209.

Elizabeth - a project of the self closely linked to money and sociability

Elizabeth was in the same year group as Sarah. She lived in a rural area some distance away from the school. Her father was a businessman - 'he buys and sells companies' - and her mother 'never worked', although she had recently completed an undergraduate degree and was planning to set up a business. There was a family history of boarding education from a young age (Elizabeth's brother closest to her in age had gone to Eton), and all her friends from home boarded in various parts of the country as well. Many of these friends also had homes in London - so Elizabeth split her out-ofschool-term time between her country home and London where she stayed with friends or with one of her brothers.

Rushby had been one of five all-girls boarding schools considered for Elizabeth's secondary education. She explained,

'I wasn't actually that keen on going to an all-girls school ... so I don't know what my like thought process was, but I was like if I don't work I won't get in, so I won't have to go ... so in my last year at my prep[aratory] school (equivalent to junior or primary school) I didn't work very hard and I kind of messed about, and I was like 'I don't want to go there',

However, because her older brothers had all gone to single-sex schools, Elizabeth's father felt it would not be fair for her to go to a co-educational school.

Rushby was therefore a 'natural fit' between Elizabeth's family background and that of many other young women with histories of private education also at the school, being relatively wealthy and living rurally, although Elizabeth would have preferred a co-educational school. However, Elizabeth's project of the self was rather different to that of Sarah and many of her other peers at Rushby: 
'I wouldn't actually say I'm good at anything in particular, because ... because there are kind of a few people in my year that strive at everything and you can't really beat them ... but I wouldn't ... I would say I was academic maybe ... but I'm ... but I'm quite lazy as well, so that's ... but I mean if I work hard I can do it ... it takes quite a lot of effort for me to work hard. I'm not sporty at all ... I'm okay at singing ... if they like have a natural talent and stuff it's annoying 'cos they don't have to work to get good results, and that annoys me. School does like to specialise in each person - but concentrates more on those who do excel than people like me.'

In addition, continuity within Elizabeth's family had been interrupted. Her mother had recently revealed that she was planning to separate from her father, and Elizabeth explained that her father's income had fluctuated while she had been growing up, which meant she had had to forego some of the entitlements to clothing and holidays she felt her brothers had benefitted from. Elizabeth's brothers all worked in banking, and while she enjoyed the subject of economics at school she appeared somewhat hesitant about being seen as simply 'following in their footsteps'. When asked how she envisaged the future, Elizabeth explained:

Elizabeth: $\quad$ Yeah I would like to be living in London and working in London and ... 'cos everyone's there having all the fun ... and then getting a good job and being successful.

Claire: $\quad$ And when you say you want to be successful, you know what does that mean to you?

Elizabeth: Um well I'd like to make lots of money, I'd like to be able to ... you know if I have children give them like more than I had and the privileges I had more.

So, despite her desire to be different from her brothers, Elizabeth still felt it important to have a job (most likely in London) in which she would earn a high salary. 
Maxwell, C. \& Aggleton, P. (2014) The reproduction of privilege: Young women, the family and private education. International Studies in Sociology of Education 24(2): 189-209.

In many ways, Elizabeth's family background was similar to Sarah's, with respect to education and financial security at least. Like Sarah, Rushby's largely ‘country’ intake fitted comfortably with Elizabeth's own experience of the world. However, her parents' view of Rushby as not 'really ... academic ... [more] ... arty and drama-y', and her own view of herself not being 'good at anything in particular', did not align with the academic and highly accomplished nature of the majority of young women interviewed at Rushby. In this way, the fit between Elizabeth and Rushby was therefore not quite as seamless as for Sarah. As shown in Figure 3, Elizabeth's orientation was shaped by the surety and expectation of familiar people, events and situations in the present and future (living comfortably financially, working in an employment sector where she could earn a lot of money), but she herself was ambivalent about being seen as a high achiever and as overtly accomplished and distinguished. 
Maxwell, C. \& Aggleton, P. (2014) The reproduction of privilege: Young women, the family and private education. International Studies in Sociology of Education 24(2): 189-209.

Figure 3. The shaping of orientations - Elizabeth

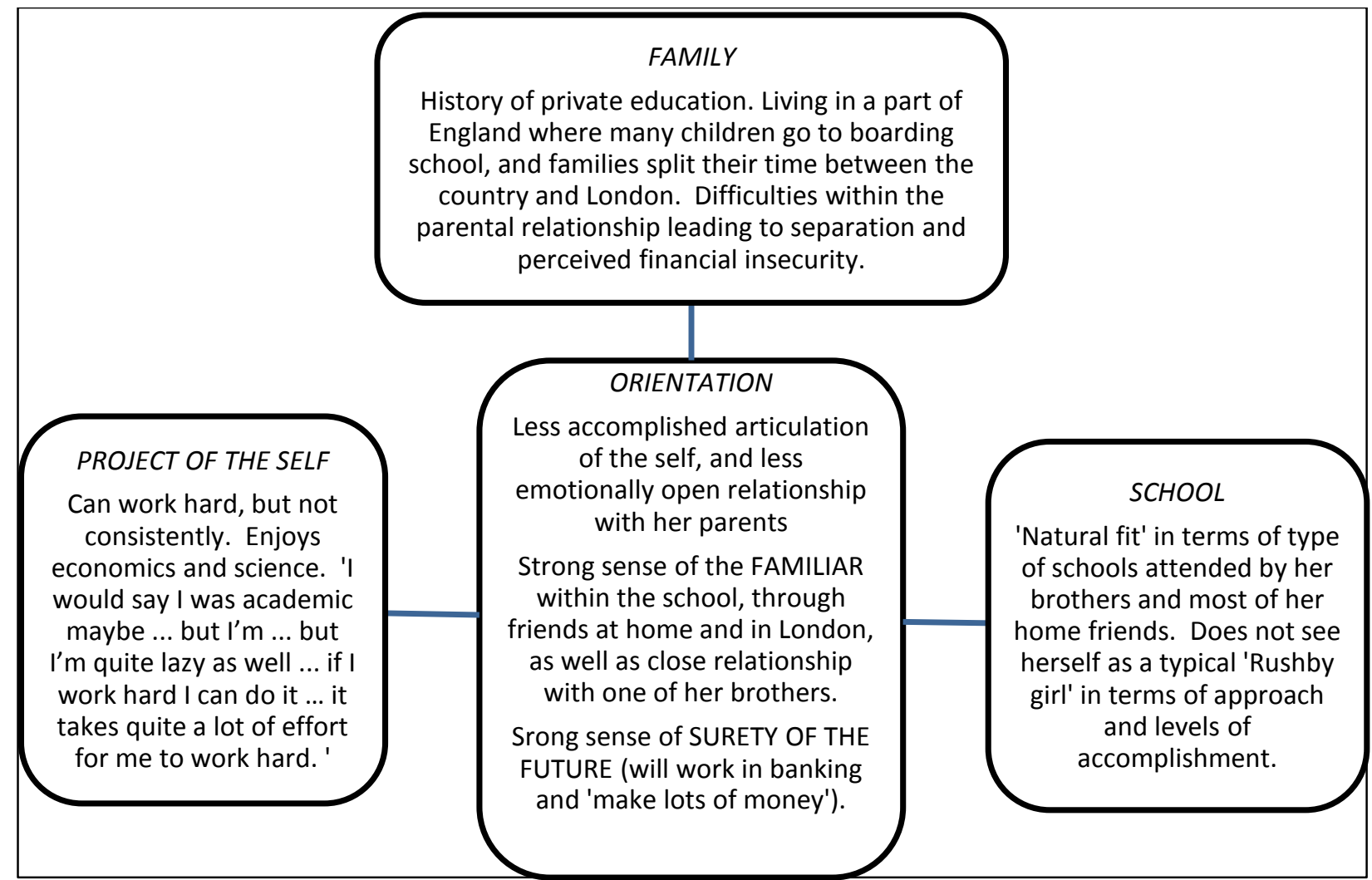

Thus, for Elizabeth, we observe a less clearly articulated trajectory conducive to economic surety, despite the aspiration to work in banking. What is interesting about her, however, is her emphasis on sociability, knowing 'the right kind of' people, balancing a life between London and 'the country', and wishing to build a future surrounded by 'similar others'. Thus for Elizabeth, privilege is grounded more in a particular kind of sociability, than in economic and cultural distinction (as perhaps evident in Sarah's experiences of life and aspired-to future through Cambridge and through theatre) but by being part of a social network connected to a particular lifestyle but which could be afforded by relatively the high levels of income likely to gained by working as a banker. 
Maxwell, C. \& Aggleton, P. (2014) The reproduction of privilege: Young women, the family and private education. International Studies in Sociology of Education 24(2): 189-209.

Alice - the affective disorientations of family history

Alice was also in Year 12 when she was first interviewed. Both her parents had been privately educated at boarding schools, with all the male members of her family having gone to Eton College. Her eldest brother was currently at Eton and her boyfriend attended Harrow School, arguably the second foremost private school for boys in England.

Alice's parents lived in London. Her father was a stockbroker in the City and her mother had been a stay-at-home parent until recently - she was now a personal secretary. Alice explained, 'my mum was home when we were all there, she's just picked up work again because we're not ... she needs to keep herself busy'. Alice was one of three children - with an older and a younger brother. Her parents had divorced when she was quite young and she described this as having had a significant effect on her life.

Alice was the only young woman in her year at school from London. Her parents had wanted her to be schooled 'away from [...] the town', but this had an effect on how she felt she fitted in:

'Cos I've grown up in London and everything it's just very different to what I'm used to, it's very like secluded and it's quite country bumpkin and all the rest of the people here - which I'm definitely not. And .. I don't know, I just prefer like a variety of people.'

Initially, Alice's parents had considered whether to send her to a well-known girls-only boarding school in another part of England, but eventually Rushby was decided on because 'they felt that it's a less .. like .. competitive and .. like .. intense in that kind of way'. However, such a perspective did not really seem to mirror the way in which Alice understood herself. Partly because of the way in which she coped with her 
Maxwell, C. \& Aggleton, P. (2014) The reproduction of privilege: Young women, the family and private education. International Studies in Sociology of Education 24(2): 189-209.

parents separation, and partly in reaction to her family's (sexist) positioning of her eldest brother as 'the clever one', her youngest brother as 'the sporty one' and herself as 'like all-roundery' - Alice believed herself to be stubborn and over-competitive, and able to give her older brother a 'run for his money' in relation to academic attainment.

'Like .. with my parents kind of separating so young ... and .. like .. growing up with quite a lot of ... not conflict ... yeah conflict ... a lot of like arguments ... I get quite ... not aggressive, but I'm quite like ... I think my aggression goes into like ... wanting to do well. And I always just think "Right, I don't want my life to end up like that" so I'm going to do something to not make it like that ... I want to kind of do the opposite to what my parents did. I really want a like good career. I don't want to be like a house mum straight away or whatever, I want to like make it ... I'm really quite set on that, like I'm quite a motivated person'.

For Alice, while family educational history and economic security fitted closely with the kind of school Rushby was, she was from 'the town', rather than 'the country' (see also Maxwell and Aggleton, 2010). Despite being very able - both academically and on the sports field - she saw herself as 'standard' in comparison to some of her other more accomplished peers who were, for example, performing in plays outside school and were more widely respected within the school for their achievements (advertised through newspaper clippings and photos prominently displayed on notice boards across the school).

Alice's presentation of herself as stubborn, aggressive and overly-competitive fits less comfortably with the privately educated, accomplished but 'quietly ambitious' young woman in Sarah's self-description (see also Wardman, Hutchesson et al. 2010). Her competitive and aggressive nature, Alice, suggested was linked to her experience of her parents' separation and the way in which she had been positioned within the family as the less note-worthy but accomplished sister. These experiences - within both the family and school - had consequences for her project of the self, and her orientation towards the future, as shown in Figure 4. 
Figure 4. The shaping of orientations - Alice

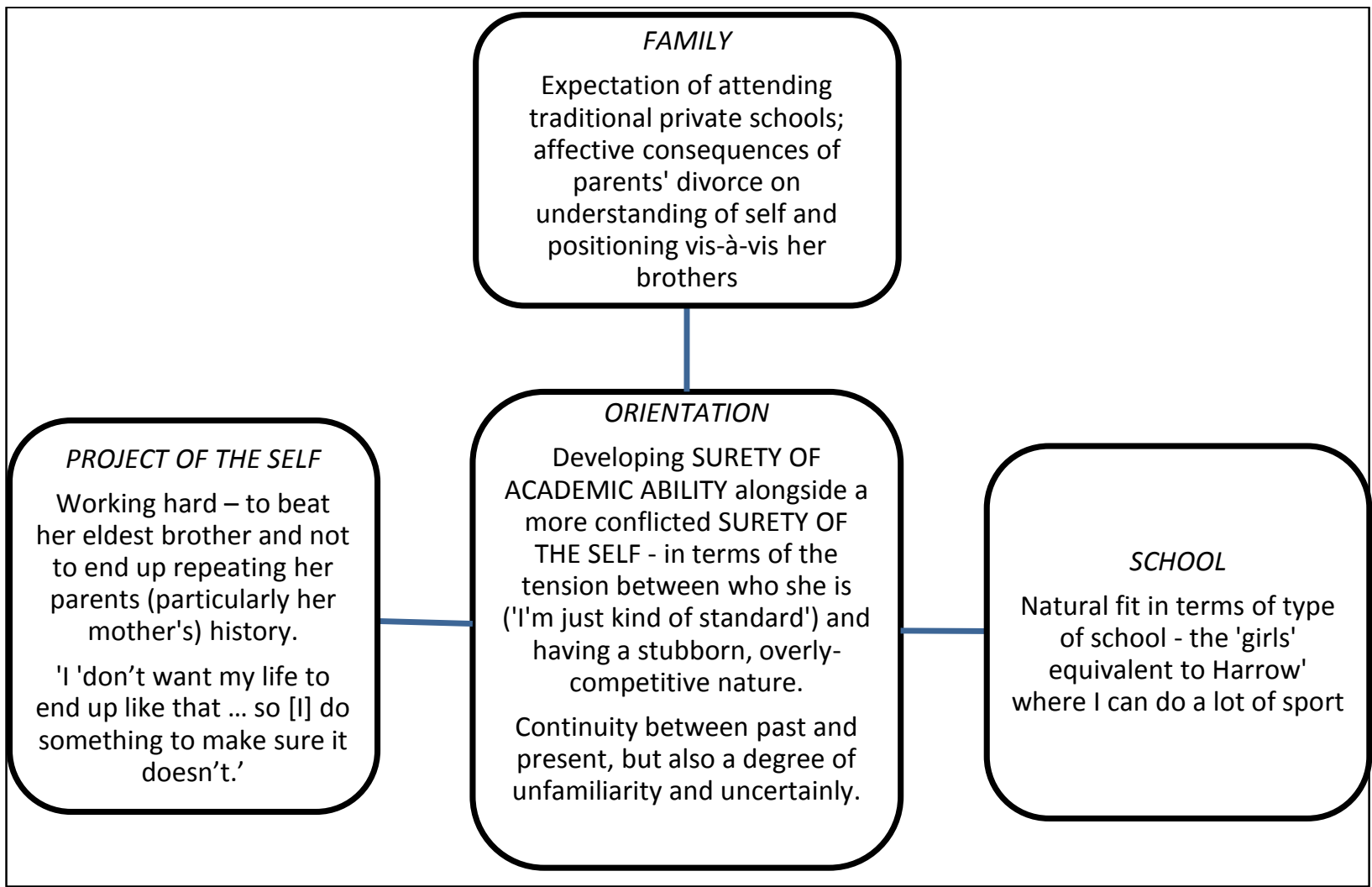

While this combination of factors may have the effect of driving practices to secure economic privilege in the future (through strong academic attainment, a university degree, not to mention social/family networks potentially supportive of employment opportunities), Alice's affective experiences within the family hold some potential to undermine the attainment of these and perhaps related outcomes. In particular, the breakup of her mother and father's relationship led her to question the life projects and gender relations in many of the families of girls attending Rushby - organised around a male breadwinner and female home-maker.

That said, Alice's critique of the negative consequences of such arrangements was tempered by a desire to get on and be a success. She explained, 
Maxwell, C. \& Aggleton, P. (2014) The reproduction of privilege: Young women, the family and private education. International Studies in Sociology of Education 24(2): 189-209.

'I really want a like good career. I don't want to be .. like .. a house mum straight away or whatever, I want to like make it ... I'm really quite set on that, like I'm quite a motivated person. Of course I want to have kids when I'm older ... [mum had children in her early twenties] I always feel that she was quite restricted and now I see her like being in part time work, and I always feel like I want to have a proper career and then step away. But of course I want to have children, and if I do I'd probably want to be at home with them, but I want to have a career first.'

Overall, Alice's narrative suggests that while her family's educational history and financial means had created opportunities for academic success, more important perhaps in determining her future trajectory were the negative experiences she had had, both at home and at the school she had been sent to. While Sarah's positive passage through schooling had provided her with a quietly confident 'surety of the self', Alice's more unsettling affective experiences - both at home and in school - contributed to a sense of self determination which, while useful, by no means guarantees her a future position among the educationally and economically most privileged members of English society, where relatively traditional gender norms around employment, and an emphasis on sociability and cultural distinction still hold sway.

\section{Conclusions}

In this paper we have outlined elements of a framework to enable more careful thinking about how resources and institutions (here - the family and the school), together with individual projects of self, shape the orientations and practices of privately educated young women. Of particular interest to us has been the potential of these practices to lead to differing forms of privilege and, through these, culturally and socially reproductive outcomes. Relatively few studies to date, especially within the literature on middle and upper-middle class young people, have examined how family, school and the self interact to shape current and future practices. Such an approach to 
Maxwell, C. \& Aggleton, P. (2014) The reproduction of privilege: Young women, the family and private education. International Studies in Sociology of Education 24(2): 189-209.

studying young women in private education is strongly influenced by Bourdieu's ideas of habitus and capitals but seeks to extend this by focusing on the role that affect plays in shaping practices (Maxwell and Aggleton, in press). We have also tried to show how the articulation of young women's projects of the self is shaped by both pre-reflexive (Nielsen, 2013) as well as new registers of meaning created within and through current and future practices. The alignment (or lack of it) between pre-reflexive, contemporary and future orientations is critical to understanding the ways in which social and cultural reproduction takes place. By examining family biographies, the school context and the manner in which young women develop projects of the self, it becomes possible to examine how particular dispositions and resources (both discursively and more materially) shape expressions of surety and privilege.

Sarah, Elizabeth and Alice all came from economically well-off families (although in Elizabeth's case, there had been a degree of instability) with histories of private education. However, their orientations towards, and their confidence in educational achievement and other kinds of accomplishment differed (as expressed in part through their projects of the self). While all three young women fitted into the ethos of Rushby School, there was a greater ambivalence about this for both Elizabeth and Alice.

Nevertheless, what Rushby, their parents and siblings offered was a sense of surety that each girl would secure a good university education and consequently a future level of economic security and privilege through high status and/or well remunerated forms of employment.

Despite their differences, each girl experienced a strong sense of continuity in terms of social location and the networks that formed part of her everyday life. This sense of place was secured in part through the friendships developed at school (including relationships with young men at other elite institutions). All three young 
Maxwell, C. \& Aggleton, P. (2014) The reproduction of privilege: Young women, the family and private education. International Studies in Sociology of Education 24(2): 189-209.

women were also familiar with the 'the country' and 'the town' (i.e. London) as they saw it, and expected their futures to include time spent in both places. However, the challenges experienced by Alice (parental divorce, the feeling that her brothers were seen as more talented than she, and her determination not to repeat her mother's trajectory) and Elizabeth (a less confident articulation of the self as 'accomplished' and able), raise questions about the smooth and unquestioning reproduction of privilege from the past into the future.

In conclusion, our concern in this paper has been both to document both the overall direction of travel as these privately educated young women take on board the opportunities through a private education, as well as to argue for a certain unpredictability of outcome. Processes of cultural and social reproduction - even for the elite or upper middle classes - are not always as straightforward as they seem; and at an individual level at least, they may be accompanied by a level of indeterminacy.

By highlighting the importance of three relatively discrete but closely articulated domains in accounting for the development of individual and more collective subjectivities, our work aims to lay the foundations for a clearer understanding of the 'gap' between the orientations young women may have, the social and cultural practices they may display, and the eventual effects to which both of these give rise. While the perspectives and actions of Sarah, Elizabeth and Alice hold the distinct potential to confer privilege, this outcome is not unproblematically achieved. Only the future will reveal whether their hoped for trajectories, and their culturally and socially reproductive effects, come to be realised. We anticipate following their progress in this respect over the coming years. 


\section{References}

Allan, A. (2009). The Importance of being a 'Lady': Hyper-femininity and Heterosexuality in the Private, Single-Sex Primary School. Gender and Education, 21(2), 145-158.

Allan, A. (2010). Picturing success: young femininities and the (im)possibilities of academic achievement in selective, single-sex education. International Studies in Sociology of Education, 20(1), 39-54.

Allan, A., \& Charles, C. (2014). Cosmo girls: Configurations of class and femininity in elite educational settings. British Journal of Sociology of Education, 35(3), 333352. doi: DOI:10.1080/01425692.2013.764148

Allard, A. C. (2005). Capitalizing on Bourdieu: How useful are concepts of 'social capital' and 'social field' for researching 'marginalized' young women? Theory and Research in Education, 3(1), 63-79.

Archer, L. (2010). 'We raised it with the Head': the educational practices of minority ethnic, middle-class families. British Journal of Sociology of Education, 31(4), 449-469.

Archer, L. (2011). Constructing Minority Ethnic Middle-class Identity: An Exploratory Study with Parents, Pupils and Young Professionals. Sociology, 45(1), 134-151.

Ball, S. J. (1997). On the cusp: parents choosing between state and private schools in the UK: action within an economy of symbolic goods. International Journal of Inclusive Education, 1(1), 1-17.

Ball, S. J., \& Vincent, C. (2007). Education, Class Fractions and the Local Rules of Spatial Relations. Urban Studies, 44(7), 1175-1190.

Ball, S. J., Vincent, C., Kemp, S., \& Pietikainen, S. (2004). Middle class fractions, childcare and the 'relational' and 'normative' aspects of class practices. The Sociological Review, 52(4), 478-502.

Bernstein, B. (1977). Class, Codes and Control. Volume 3. London: Routledge.

Brantlinger, E. (2003). Dividing classes: How the middle class negotiates and rationalizes school advantage. London: Routledge.

Charles, C. (2010). Complicating hetero-femininities: Young women, sexualities and 'girl power' at school. International Journal of Qualitative Studies in Education, 23(1), 33-47.

Clark, S. (2009). A good education: girls' extracurricular pursuits and school choice. Gender and Education, 21(5), 601-615.

Connell, R., Ashenden, D., Kessler, S., \& Dowsett, G. (1982). Making the Difference: Schools, Families and Social Division. Sydney: Allen \& Unwin.

Crozier, G., Reay, D., \& James, D. (2011). Making it work for their children: White middle-class parents and working-class schools. International Studies in Sociology of Education, 21(3), 199-216.

Davey, G. (2012a). Beyond a binary model of students' educational decision-making. Sociological Research Online, 17(3).

Davey, G. (2012b). Using Bourdieu's concept of doxa to illuminate classed practices in an English fee-paying school. British Journal of Sociology of Education, 33(4), 507-525.

Forbes, J., \& Lingard, B. (2013). Elite school capitals and girls' schooling: Understanding the (re)production of privilege through a habitus of 
Maxwell, C. \& Aggleton, P. (2014) The reproduction of privilege: Young women, the family and private education. International Studies in Sociology of Education 24(2): 189-209.

'assuredness'. In C. Maxwell \& P. Aggleton (Eds.), Privilege, Agency and Affect (pp. 50-68). Basingstoke: Palgrave Macmillan.

Forbes, J., \& Weiner, G. (2008). Under-stated powerhouses: Scottish independent schools, their characteristics and their capitals. Discourse: Studies in the Cultural Politics of Education, 29(4), 509-525.

Gaztambide-Fernández, R. (2009a). The Best of the Best: Becoming elite at an American boarding school. Cambridge, MA: Harvard University Press.

Gaztambide-Fernández, R. (2009b). What Is an Elite Boarding School? Review of Educational Research, 79(3), 1090-1128.

Gaztambide-Fernández, R., Cairns, K., \& Desai, C. (2013). The sense of entitlement. In C. Maxwell \& P. Aggleton (Eds.), Privilege, Agency and Affect (pp. 32-49). Basingstoke: Palgrave Macmillan.

Hollingworth, S. (2013). Social mixing and non-normative gendered, classed and raced performances in the urban school: The 'misfits'. Paper presented at the Education and Learning: Sociological Perspectives, University of Surrey, Guildford.

Hollingworth, S., \& Williams, K. (2009). Constructions of the working-class 'Other' among urban, white, middle-class youth: 'Chavs', subculture and the valuing of education. Journal of Youth Studies, 12(5), 467-482.

Horne, J., Lingard, B., Weiner, G., \& Forbes, J. (2011). 'Capitalizing on Sport': Sport, Physical Education and Multiple Capitals in Scottish Independent Schools. British Journal of Sociology of Education, 32(6), 861-879.

Howard, A. (2008). Learning privilege: lessons of power and identity in affluent schooling. New York: Routledge.

Howard, A. (2013). Negotiating privilege through social justice efforts. In C. Maxwell \& P. Aggleton (Eds.), Privilege, Agency and Affect (pp. 185-201). Basingstoke: Palgrave Macmillan.

Irwin, S., \& Elley, S. (2011). Concerted cultivation? Parenting values, education and class diversity. Sociology, 45(3), 480-495.

Irwin, S., \& Elley, S. (2013). Parents' hopes and expectations for their children's future occupations. The Sociological Review, 61(1), 111-130.

Kenway, J., Fahey, J., \& Koh, A. (2013). The libidinal economy of the globalising elite school market. In C. Maxwell \& P. Aggleton (Eds.), Privilege, Agency and Affect (pp. 15-31). Basingstoke: Palgrave Macmillan.

Khan, S. R. (2011). Privilege: The making of an adolescent elite at St. Paul's School. Princeton: Princeton University Press.

Koh, A., \& Kenway, J. (2012). Cultivating national leaders in an elite school: Deploying the transnational in the national interest. International Studies in Sociology of Education, 22(4), 333-351.

Lareau, A. (2002). Invisible inequality: Social class and childrearing in black families and white families. American Sociological Review, 67(5), 747-776.

Lawler, S. (2005). Disgusted subjects: The making of middle-class identities. Sociological Review, 53(3), 429-446.

Maxwell, C., \& Aggleton, P. (2010). The bubble of privilege. Young, privately educated women talk about social class. British Journal of Sociology of Education, 31(1), 3-15.

Maxwell, C., \& Aggleton, P. (2013a). Becoming accomplished: Concerted cultivation among privately educated young women. Pedagogy, Culture \& Society, 21(1), 75-93. 
Maxwell, C. \& Aggleton, P. (2014) The reproduction of privilege: Young women, the family and private education. International Studies in Sociology of Education 24(2): 189-209.

Maxwell, C., \& Aggleton, P. (in press). Agentic practice and privileging orientations among privately educated young women. The Sociological Review.

Maxwell, C., \& Aggleton, P. (Eds.). (2013b). Privilege, agency and affect. Basingstoke: Palgrave Macmillan.

McIntosh, P. (1990). White privilege: unpacking the invisible knapsack. Independent School, Winter.

Méndez, M. L. (2008). Middle class identities in a neoliberal age: tensions between contested authenticities. The Sociological Review, 56(2), 220-237.

Meo, A. I. (2011). Zafar, so good: middle-class students, school habitus and secondary schooling in the city of Buenos Aires (Argentina). British Journal of Sociology of Education, 32(3), 349-367.

Nielsen, H. B. (2013). Gender on class journeys. In C. Maxwell \& P. Aggleton (Eds.), Privilege, Agency and Affect (pp. 202-218). Basingstoke: Palgrave Macmillan.

O'Flynn, G., \& Petersen, E. B. (2007). The 'good life' and the 'rich portfolio': young women, schooling and neoliberal subjectification. British Journal of Sociology of Education, 28(4), 459-472.

Pini, B., McDonald, P., \& Mayes, R. (2012). Class contestations and Australia's resource boom: The emergence of the 'cashed-up bogan'. Sociology, 46(1), 142158.

Power, S., Curtis, A., Whitty, G., \& Edwards, T. (2010). Private education and disadvantage: the experiences of Assisted Place holders. International Studies in Sociology of Education, 20(1), 23-38.

Proweller, A. (1998). Constructing Female Identities. Meaning making in an upper middle class youth culture. Albany: State University of New York Press.

Reay, D. (2007). 'Unruly Places': Inner-city Comprehensives, Middle-class Imaginaries and Working-class Children. Urban Studies, 44(7), 1191-1201.

Reay, D., Crozier, G., \& Clayton, J. (2009). Strangers in Paradise'? Working-class students in elite universities. Sociology, 43(6), 1103-1121.

Reay, D., Crozier, G., \& James, D. (2011). White Middle Class Identities and Urban Schooling. Basingstoke: Palgrave Macmillan.

Renold, E., \& Allan, A. (2006). Bright and Beautiful: High achieving girls, ambivalent femininities, and the feminization of success in the primary school. Discourse: Studies in the Cultural Politics of Education, 27(4), 457-474.

Stefansen, K., \& Aarseth, H. (2011). Enriching intimacy: The role of the emotional in the 'resourcing' of middle-class children. British Journal of Sociology of Education, 32(3), 389-405.

Thomson, R. (2000). Dream On: The Logic of Sexual Practice. Journal of Youth Studies, 3(4), 407-427.

Thomson, R., Henderson, S., \& Holland, J. (2003). Making the Most of What You've Got? Resources, Values and Inequalities in Young Women's Transitions to Adulthood. Educational Review, 55(1), 33-46.

Vincent, C., \& Ball, S. J. (2007). 'Making Up' the Middle-Class Child: Families, Activities and Class Dispositions. Sociology, 41(6), 1061-1077.

Vincent, C., Rollock, N., Ball, S., \& Gillborn, D. (2012). Being strategic, being watchful, being determined: Black middle-class parents and schooling. British Journal of Sociology of Education, 33(3), 337-354.

Walford, G. (2012). Privatization and Privilege in Education. London: Routledge.

Wardman, N., Hutchesson, R., Gottschall, K., Drew, C., \& Saltmarsh, S. (2010). Starry eyes and subservient selves: Portraits of 'well-rounded' girlhood in the 
Maxwell, C. \& Aggleton, P. (2014) The reproduction of privilege: Young women, the family and private education. International Studies in Sociology of Education 24(2): 189-209.

prospectuses of all-girl elite private schools. Australian Journal of Education, 54(3), 249-261. 